SANDRA ŚWITAŁA

Instytut Politologii UMK

\title{
Prezydent Rzeczypospolitej Polskiej w świetle konstytucji z 1997 roku. Regulacja i jej oceny
}

\section{Słowo wstępne}

Dozycję ustrojową prezydenta wyznaczają w dużej mierze: sposób wyboru, przyznane funkcje ustrojowe oraz kompetencje. Wszystkie te kwestie - w odniesieniu do polskiej głowy państwa - reguluje w chwili obecnej Konstytucja Rzeczypospolitej Polskiej z 2 kwietnia 1997 roku. Od tego, czy zapisy konstytucyjne dotyczące modelu wyboru prezydenta, a także powierzonych mu funkcji i uprawnień są ze sobą spójne i przystają do siebie oraz czy przejrzyście i jasno ustalają, co należy do sfery działania prezydenta, a co stanowi kompetencję innych organów (w szczególności drugiego członu władzy wykonawczej, a więc rady ministrów z premierem na czele) - zależy to, jak są one oceniane.

Niniejszy artykuł ma na celu krótkie przybliżenie sposobu, w jaki obowiązująca w Polsce ustawa zasadnicza reguluje instytucję głowy państwa, a następnie zaprezentowanie tego, jak oceniają ją naukowcy (konstytucjonaliści, politolodzy, socjolodzy i inni), politycy, publicyści, a także opinia publiczna.

\section{Regulacja}

Wybór prezydenta uregulowano w artykule 127 i następnych konstytucji oraz w ustawie z 27 września 1990 r. o wyborze Prezydenta Rzeczypospolitej Polskiej, do której przepisy konstytucyjne odsyłają. Spośród trzech 
możliwych sposobów elekcji, a więc: 1) wyboru na zasadzie powszechnego prawa wyborczego; 2) przez izby parlamentarne lub 3) przez specjalny, odrębny organ ${ }^{1}$, polski ustrojodawca wybrał ten pierwszy. Zgodnie z ustawą zasadniczą, prezydent jest wybierany przez naród w wyborach powszechnych, równych, bezpośrednich i w głosowaniu tajnym na pięcioletnią kadencję, z możliwością jednokrotnego ponownego wyboru. By zostać szefem państwa zwycięski kandydat musi zdobyć ponad 50\% głosów. Jeśli taka „sztuka” nie uda się żadnemu z pretendentów do urzędu, przeprowadza się tzw. drugą turę, w której rywalizuje dwóch kandydatów, którzy w pierwszym z głosowań otrzymali największą liczbę głosów.

We wspomnianej ustawie o wyborze Prezydenta RP szczegółowo uregulowano zasady zgłaszania kandydatur, kampanii wyborczej, samego głosowania oraz obliczania jego wyników i podawania ich do publicznej wiadomości. Określono również limit wydatków kandydata na kampanię, który wynosi 12 mln złotych, a także zobowiązano publiczne radio i telewizję do emitowania audycji komitetów wyborczych - aby jak najlepiej i najpełniej przedstawić społeczeństwu wszystkich kandydatów.

Jak słusznie podnoszą Sylwester Wróbel i Rafał Grajcar, utrzymanie powszechności wyboru głowy państwa miało miejsce równolegle z osłabieniem pozycji prezydenta w porównaniu z latami 1992-1997. „Można w związku z tym zadać sobie pytanie, czy elekcja prezydenta w głosowaniu powszechnym jest uzasadniona?" Zdaniem Jerzego Ciapały „wybory powszechne z natury swej wzmacniają pozycję prezydenta [...], [a] elekcja bezpośrednia wpływa niewątpliwie na ugruntowanie legalnej legitymacji władzy"3.

O roli prezydenta oprócz sposobu wyboru decydują przyznane mu przez konstytucyjnego ustawodawcę funkcje ustrojowe. Traktuje o nich artykuł 126 ustawy zasadniczej, charakteryzując ich istotę. Przepis ten stanowi, iż prezydent jest najwyższym przedstawicielem Rzeczypospolitej Polskiej i gwarantem ciągłości władzy państwowej. Czuwa on nad przestrzeganiem konstytucji, stoi na straży suwerenności i bezpieczeństwa państwa oraz nienaruszalności i niepodzielności jego terytorium. Głównie na podstawie tego właśnie zapisu J. Ciapała wyróżnia cztery funkcje ustrojowe Prezydenta Rzeczypospolitej: „1) głowy państwa; 2) organu czuwającego nad przestrzega-

Zob. szerzej na temat każdego ze sposobów: J. Ciapała, Prezydent $w$ systemie ustrojowym Polski, Warszawa 1999, s. 55 i nast.

$2 \quad$ R. Grajcar, S. Wróbel, Instytucja Prezydenta w świetle Konstytucji Rzeczypospolitej Polskiej z dnia 2 kwietnia 1997 roku, w: Instytucja prezydenta i wybory prezydenckie 2000 roku. Studia i szkice, red. S. Wróbel, Bielsko-Biała 2003, s. 21.

J. Ciapała, dz. cyt., s. 56-57. 
niem konstytucji; 3) organu mającego do spełnienia istotne zadania w dziedzinie bezpieczeństwa państwa; 4) organu odgrywającego znaczącą rolę w dziedzinie stosunków międzynarodowych"4.

Uczynienie prezydenta „najwyższym przedstawicielem Rzeczypospolitej" oznacza powierzenie piastunowi tego urzędu funkcji głowy państwa5 To z kolei jest równoznaczne z uznaniem go za „żywy” symbol państwa będący personifikacją majestatu Rzeczypospolitej. Według J. Ciapały pełni on podobną rolę jak symbole "martwe”, czyli godło, flaga i hymn państwowy, a ponadto prezydent jest „uznawany za upoważnionego do dokonywania aktów najwyższej reprezentacji państwa, do czynności, poprzez które obecne jest niejako samo państwo polskie"6.

Prezydent to nie tylko głowa państwa, „poza Trybunałem Konstytucyjnym, jest drugim organem, którego działalność tak jednoznacznie ma służyć respektowaniu porządku konstytucyjnego"”. Do jego obowiązków należy więc nie tylko - wynikające z zasady legalizmu i odnoszące się do wszystkich organów państwa - przestrzeganie przepisów prawa, ale też podejmowanie działań prowadzących do respektowania konstytucji również przez inne podmioty 8 .

Zgodnie z art. 126 ust. 2 obowiązującej ustawy zasadniczej prezydent oprócz czuwania nad przestrzeganiem konstytucji - stoi na straży suwerenności i bezpieczeństwa państwa oraz nienaruszalności i niepodzielności jego terytorium. Jest więc organem, któremu przyznano pewne uprawnienia w dziedzinie bezpieczeństwa państwa, choć - inaczej niż w przypadku małej konstytucji - nie sprawuje już w tej sferze ogólnego kierownictwa.

W świetle przepisów konstytucyjnych prezydent jest najwyższym zwierzchnikiem Sił Zbrojnych RP (art. 134 ust. 1). Przy czym, w czasie pokoju sprawuje on zwierzchnictwo za pośrednictwem Ministra Obrony Narodowej i choć mianuje on Szefa Sztabu Generalnego i dowódców rodzajów Sił Zbrojnych na czas określony, to na czas wojny prezydent mianuje Naczelnego Dowódcę Sił Zbrojnych na wniosek Rady Ministrów i tylko w takim trybie może go odwołać. Oznacza to, że prezydent pełni zwierzchnictwo symboliczne, faktycznie zaś większą rolę odgrywa Rada Ministrów. Zgodnie bowiem z przepisami ustawy zasadniczej to rząd ma zapewnić bezpieczeństwo wewnętrzne, porządek publiczny i bezpieczeństwo zewnętrzne i do niego należy sprawowanie ogólnego kierownictwa w dziedzinie obronności kraju.

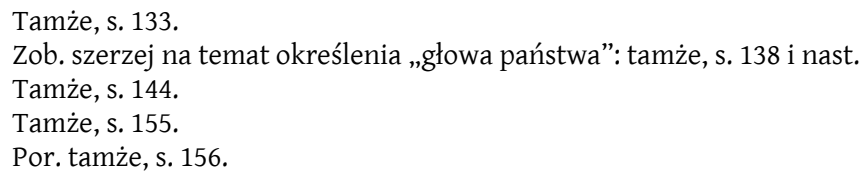


Prezydent może oddziaływać na politykę państwa i współdecydować o jej kierunku poprzez uprawnienia o charakterze niewładczym, a więc przez zwoływanie Rady Gabinetowej oraz przez kierowanie Radą Bezpieczeństwa Narodowego (organem doradczym prezydenta w zakresie wewnętrznego i zewnętrznego bezpieczeństwa państwa - art. 135).

W obowiązującej konstytucji rola prezydenta uległa zmniejszeniu nie tylko w kwestii uprawnień dotyczących bezpieczeństwa państwa, ale także tych dotyczących stosunków międzynarodowych. „Zasadnicza konstatacja wyraża się w przyjęciu, że jest ona bardziej pochodną statusu głowy państwa (najwyższego przedstawiciela) niż organu władczo-politycznego. [...] Osłabienie funkcji prezydenta nastąpiło $\mathrm{w}$ rezultacie odstąpienia od formuły ogólnego kierownictwa w dziedzinie stosunków zagranicznych i przyznania tej funkcji rządowi"' (art. 146 ust. 9).

Do funkcji głowy państwa jako organu posiadającego pewne uprawnienia w dziedzinie stosunków międzynarodowych odnosi się art. 133 konstytucji. W jego świetle prezydent jako reprezentant państwa w stosunkach zewnętrznych: 1) ratyfikuje i wypowiada umowy międzynarodowe, o czym zawiadamia sejm i senat; 2) mianuje i odwołuje pełnomocnych przedstawicieli Rzeczypospolitej w innych państwach i przy organizacjach międzynarodowych; 3) przyjmuje listy uwierzytelniające i odwołujące akredytowanych przy nim przedstawicieli dyplomatycznych innych państw i organizacji międzynarodowych. Może on także przed ratyfikowaniem umowy międzynarodowej zwrócić się do Trybunału Konstytucyjnego z wnioskiem w sprawie jej zgodności z konstytucją i co bardzo ważne w zakresie polityki zagranicznej współdziała z prezesem Rady Ministrów i właściwym ministrem.

Przechodząc od funkcji ustrojowych głowy państwa do jej konkretnych kompetencji, należy podkreślić, że uprawnienia prezydenta ograniczają się do tych wymienionych w konstytucji, co oznacza, że domniemanie kompetencji w łonie władzy wykonawczej działa na korzyść i na rzecz rzą$\mathrm{du}^{10}$. Ustawa zasadnicza nadaje prezydentowi (w art. 144 ust. 3) 30 prerogatyw, a więc uprawnień własnych - nie wymagających kontrasygnaty premiera. Pozostałe działania odbywają się już za zgodą prezesa Rady Ministrów, muszą być bowiem opatrzone jego podpisem, który to przenosi odpowiedzialność z prezydenta na premiera.

Wśród najważniejszych prerogatyw wymienić należy: skracanie kadencji Sejmu w przypadkach określonych w konstytucji; inicjatywę ustawodawczą; zarządzanie referendum ogólnokrajowego; podpisywanie albo od-

Tamże, s. 218-219.

10 Por. Prawo konstytucyjne, red. Z. Witkowski, Toruń 2006, s. 432. 
mowę podpisania ustawy; zarządzanie ogłoszenia ustawy oraz umowy międzynarodowej w Dzienniku Ustaw Rzeczypospolitej Polskiej; wniosek do Trybunału Konstytucyjnego; desygnowanie i powoływanie prezesa Rady Ministrów; przyjmowanie dymisji Rady Ministrów i powierzanie jej tymczasowego pełnienia obowiązków; wniosek do sejmu o pociągnięcie do odpowiedzialności przed Trybunałem Stanu członka rady ministrów; zwoływanie Rady Gabinetowej; nadawanie orderów i odznaczeń; powoływanie sędziów; stosowanie prawa łaski; nadawanie obywatelstwa polskiego i wyrażanie zgody na zrzeczenie się go; a także powoływanie: pierwszego prezesa Sądu Najwyższego, prezesa i wiceprezesa Trybunału Konstytucyjnego, prezesa Naczelnego Sądu Administracyjnego, członków Rady Polityki Pieniężnej, Krajowej Rady Radiofonii i Telewizji oraz powoływanie i odwoływanie członków Rady Bezpieczeństwa Narodowego.

\section{Oceny}

Dalsza część niniejszego artykułu zawierać będzie przegląd opinii i komentarzy na temat sposobu, w jaki uregulowano instytucję polskiej głowy państwa oraz zgłaszanych propozycji zmian. Przytoczone zostaną oceny naukowców, polityków, dziennikarzy, a także zostanie zaprezentowany społeczny odbiór władzy prezydenta. Kwestia ta jest szczególnie warta uwagi ze względu na pojawiające się w ostatnim czasie spory na linii prezydent Lech Kaczyński - premier Donald Tusk, szeroko prezentowane i komentowane w mediach.

W pierwszej kolejności przedstawione zostaną oceny ludzi nauki, począwszy od konstytucjonalistów. W kontekście toczącego się aktualnie sporu między prezydentem a premierem odnośnie uprawnień szefa rządu i szefa państwa w dziedzinie spraw zagranicznych, głos w dyskusji na temat konstytucyjnej regulacji dotyczącej głowy państwa zabrali byli prezesi Trybunału Konstytucyjnego: Andrzej Zoll, Marek Safjan i Jerzy Stępień. Wydali oni oświadczenie, w którym uznali, że: „Nie sprawdza się założenie zachowania równowagi między władzą parlamentu, prezydenta, premiera, oparte na koncepcji wzajemnego hamowania się poszczególnych władz. Obecna konstytucja nie rozstrzyga wystarczająco precyzyjnie, zwłaszcza w sferze władzy wykonawczej, o kompetencjach Prezydenta i szefa rządu. Konstytucja sytuuje Prezydenta w charakterze mediatora i arbitra ponad podziałami politycznymi, co okazuje się rozwiązaniem nieskutecznym w polskich realiach. W takiej sytuacji jesteśmy zdecydowani wystąpić z propozycją dokonania szybkich zmian w Konstytucji, które umożliwią wyjście z istniejącego paraliżu konstytucyjnego. Nie opowiadamy się za żadnym modelem: czy to gabine- 
towym, czy to prezydenckim. Uważamy natomiast, że wyraźne opowiedzenie się Konstytucji za którymkolwiek z tych modeli, w sposób jednoznaczny i precyzyjny rozstrzygające o charakterze ustrojowym państwa, przeprowadzające jasno cezurę między kompetencjami najważniejszych organów naszego kraju staje się palącą koniecznością" ${ }^{11}$.

Marek Safjan twierdzi również, że konflikt między prezydentem a rządem pokazuje, że zmiana ustawy zasadniczej jest konieczna. Za najbardziej niepokojącą oznakę sporu uważa on nieporozumienia w dziedzinie polityki zagranicznej. I choć - jak podkreśla w wywiadzie - wcześniej był zdania, że nie powinno się zmieniać konstytucji zależnie od sytuacji politycznej czy tym bardziej - osobowości polityków oraz, że z czasem uda się wypracować standardy zachowań, które pozwolą uniknąć konfliktów i „paraliżu politycznego”, to teraz uważa, iż „nie można konstruować systemu politycznego z nadzieją, że władzę będą sprawować osoby realizujące idealne standardy współpracy i odpowiedzialności za państwo. Prawo musi amortyzować charaktery polityków"12.

Zbigniew Witkowski zwraca natomiast uwagę na nieprzystawalność sposobu elekcji głowy państwa i przyznanych jej uprawnień. Jego zdaniem: „konstytucja, będąc dziełem kompromisu [...], odchodzi od dotychczasowej postaci systemu parlamentarnego dokonując jego dalszej racjonalizacji. Prezydent pomniejszył generalnie swój zakres oddziaływania na mechanizm ustrojowy państwa i tym samym [...] osłabieniu uległa jego pozycja ustrojowa, chociaż nie nastąpiła żadna zmiana, gdy chodzi o sposób wyboru Prezydenta [...]; utrzymanie jego powszechnego wyboru stanowi jedną z największych niespójności i niekonsekwencji nowej ustawy zasadniczej"13. Dobitniej opinię autora opisuje stwierdzenie: „Model wyborów powszechnych nijak nie przystaje do ogólnej, osłabionej przecież koncepcji prezydentury polskiej w obecnej konstytucji"14.

Marian Grzybowski w artykule Władza wykonawcza w Konstytucji $R P^{15}$ również zwraca uwagę na niejasności i niekonsekwencje przepisów obowią-

11 M. Safjan, J. Stępień, A. Zoll, Oświadczenie byłych prezesów Trybunału Konstytucyjnego, [http://wyborcza.pl/1,75478,6237771,Oswiadczenie_bylych_Prezesow_Trybunalu_Konstyt ucyjnego.html; dostęp: 15.05.2009].

12 M. Safjan, Prawo musi brać pod uwage charaktery polityków, [http://wyborcza.pl/ ,75478,6237388,Prawo_musi_brac_pod_uwage_charaktery_politykow.html; dostęp: 15.05. 2009].

13 Prawo konstytucyjne, dz. cyt., s. 432.

14 Tamże, s. 404.

15 M. Grzybowski, Władza wykonawcza w Konstytucji RP, w: O potrzebie zmian Konstytucji Polski i Ukrainy. Międzynarodowa Konferencja Naukowa Krasiczyn-Rzeszów 19-21 IX 2005, red. K. Eckhardt, W. Skrzydło, W. Szapował, Przemyśl 2006. 
zującej konstytucji a także wskazuje na „dysonans pomiędzy trybem wyboru Prezydenta RP ( $w$ wyborach powszechnych i bezpośrednich, z progiem bezwzględnej większości głosów ważnych w I turze) a relatywnie skromnym pakietem kompetencji samodzielnie realizowanych przez piastuna tej funkcji państwowej" ${ }^{16}$. Za nieprecyzyjną uważa on także regulację obejmującą ustrojowe funkcje polskiej głowy państwa. „Niejasne jest, w jakim zakresie reprezentowania Rzeczypospolitej Prezydent RP zachowuje samodzielność (i samoistność) swych działań będąc - realnie «najwyższym przedstawicielem Rzeczypospolitej» [...], w którym zaś zakresie «reprezentując państwo» winien «wpisać się» w nurt polityki prowadzonej przez Radę Ministrów"17. Za nieklarowny uważa również autor sposób sformułowania w konstytucji roli prezydenta jako „najwyższego zwierzchnika Sił Zbrojnych”. Jego zdaniem nie jest jasne, „co znaczy - jurydycznie - wykonywanie zwierzchnictwa «za pośrednictwem» [Ministra Obrony Narodowej]? Czy bez pośrednictwa zwierzchnictwo istnieje, ale nie może być «skonsumowane»? Nadto, jak tak realizowana rola ustrojowa ma się do «ogólnego kierownictwa w dziedzinie obronności kraju» sprawowanego przez Radę Ministrów"18.

Bogusław Banaszak i Mirosław Granat w artykule 0 projektach zmiany Konstytucji RP z $1997 \mathrm{roku}^{19}$ podkreślają, że relacja między organami władzy wykonawczej - złożonej w Polsce z głowy państwa i Rady Ministrów „nie stanowi realizacji żadnego ze znanych modeli ukształtowanych w państwach demokratycznych. Stanowi mieszankę systemu kanclerskiego i prezydencjalnego" ${ }^{\prime 20}$. Za element zaczerpnięty $\mathrm{z}$ tego pierwszego, uznają konstruktywne wotum nieufności, z drugiego zaś - wymóg kontrasygnowania niektórych aktów prezydenckich przez premiera i właściwego ministra oraz zwolnienie ze współpodpisu części aktów zwanych prerogatywami.

Zdaniem autorów „przyjęcie elementów dwóch różnych modeli powoduje eklektyzm regulacji prawnej i jej niespójność. Nie można równocześnie opowiadać się za mocnym prezydentem i mocnym premierem. Zwłaszcza w warunkach tzw. koabitacji ów konstrukcyjny eklektyzm może prowadzić do poważnych sporów kompetencyjnych i kryzysów politycznych" ${ }^{\text {"1 }}$. Uważają oni, że jeśli całkowita zmiana konstytucji stałaby się możliwa, należałoby wprowadzić w Polsce ,jeden ze sprawdzonych w państwach

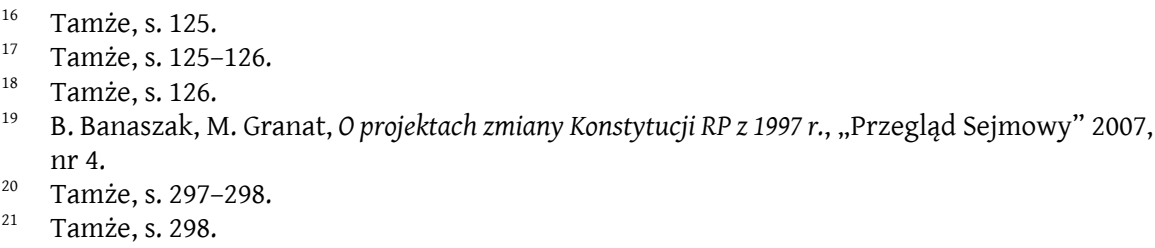


demokratycznych modeli egzekutywy"22, w przypadku zaś braku przesłanek do uchwalenia nowej ustawy zasadniczej, by „wprowadzić pewien rygoryzm do rozwiązań dotychczasowych, [gdyż] umożliwiłoby to usprawnienie rządzenia państwem"23.

Anna Materska-Sosnowska twierdzi z kolei, iż warto podjąć dyskusję na temat rozwiązań przyjętych $\mathrm{w}$ obowiązującej ustawie zasadniczej, pod warunkiem jednak, że nie zmieni się ona w „spór czysto osobowy”. Jej zdaniem, zmiany mogłyby polegać bądź na osłabieniu pozycji prezydenta - na przykład poprzez pozbawienie go prawa weta, bądź na jej wzmocnieniu poprzez rozszerzenie jego prawa do mianowań i odwołań ministrów oraz przyznania prawa do „realnego uczestnictwa w codziennej polityce”24.

Antoni Dudek nie widzi jednego dobrego rozwiązania. Twierdzi on: „Można zignorować wolę większości i zmienić zasady, aby prezydenta wybierało Zgromadzenie Narodowe. Można też pójść w kierunku systemu prezydenckiego, ale na taki model nie zgodzą się elity polityczne. Nie ma z resztą takiej tradycji w Europie"25. Zgadza się z tym Antoni Kamiński, podkreślając, że „w Polsce system prezydencki nie ma tradycji. Łatwiej jest ulepszyć dotychczasowy system. Prezydent powinien być wybierany przez Zgromadzenie Narodowe"26.

Obok krytycznych ocen obowiązującej regulacji pojawiają się głosy biorące w obronę ustawę zasadniczą z 1997 roku. Piotr Winczorek uważa, że „konstytucja w obecnym kształcie umożliwia bezkonfliktowe współdziałanie prezydenta i premiera, ale potrzeba do tego dobrej woli rządzących polityków”27. W jednym z wywiadów mówi: „nasza konstytucja nie wymaga radykalnych zmian", a na pytanie o kwestię uregulowania relacji na linii prezydent-premier odpowiada: „w tym przypadku rzecz nie w tym, jaka jest konstytucja, tylko jakie są osoby na tych stanowiskach. Zanim cokolwiek zostanie zmienione $\mathrm{w}$ ustawie zasadniczej, to obaj panowie powinni dogadać się między sobą". Ustosunkowując się do zarzutu, że obowiązująca w Polsce ustawa zasadnicza jest nieprecyzyjna, na przykład w kwestii kształtowania i prowadzenia polityki zagranicznej P. Winczorek podkreśla, że na świecie nie ma konstytucji, która byłaby $\mathrm{w}$ stu procentach precyzyjna, ponieważ z samego założenia to akt dotyczący tak rozległej materii, że musi on zawie-

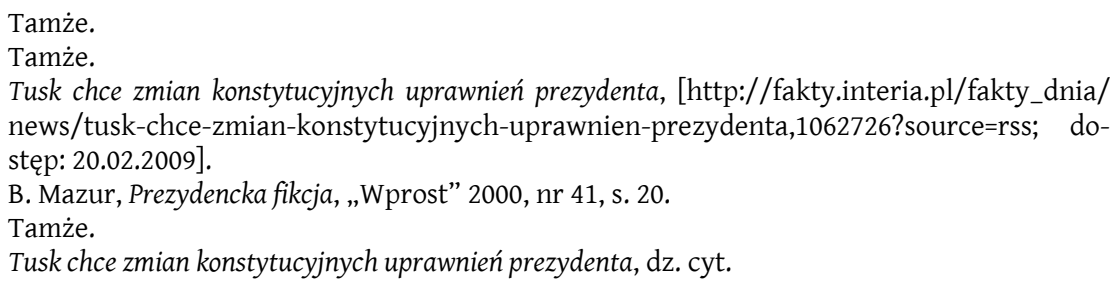


rać przepisy ogólne. Odnosząc się natomiast do propozycji uregulowania w konstytucji spornych kwestii, na przykład dotyczących tego, kto ma reprezentować Polskę na szczytach unijnych, mówi on: „Jeśli zapiszemy, że nasz kraj na spotkaniach krajów UE ma reprezentować premier, to od razu pojawia się problem, kto ma jechać do Republiki Południowej Afryki, kto ma jechać na szczyt NATO, kto ma nas reprezentować w spotkaniach ONZ-u i tak dalej [...] Nie możemy doprowadzić do sytuacji, gdzie nasza ustawa zasadnicza będzie liczyć 2000 artykułów. Konstytucja to nie jest książka kucharska"28.

Sceptyczny wobec pomysłów zmian konstytucji jest również Radosław Markowski. W jednym z wywiadów podkreśla on, że „systemy bardzo podobne do naszego funkcjonują w kilku europejskich krajach, bardzo szanowanych, stabilnych i porządnych demokracjach, na przykład w Finlandii, Austrii, Portugalii”. Stwierdza też, że jako obywatel jest przerażony perspektywą zmiany konstytucji podyktowaną tym, że prezydent i premier nie mogą się porozumieć. Uważa, że osobowość rządzących nie może być powodem zmian w ustawie zasadniczej. Jednoznacznie sprzeciwia się implementacji w Polsce modelu prezydenckiego. „Jeśli cokolwiek zmieniać, to byłbym zdecydowanie za wprowadzeniem modelu mieszanego, dokładnego skopiowania modelu niemieckiego [...] prezydent pełniłby rolę [...] politycznie ograniczoną, ale prestiżowo ważną"29.

Opinie przedstawicieli świata nauki mają charakter doradczy, jednak przeważnie nie posiadają realnego wpływu na zmiany polityczne. Inaczej rzecz ma się z koncepcjami prezentowanymi przez ugrupowania polityczne, które poprzez udział w bieżącej polityce mają możliwość realizacji. Kolejna część artykułu prezentuje, w jaki sposób regulację dotyczącą instytucji polskiej głowy państwa odbierają ugrupowania polityczne i ich przedstawiciele oraz, jak (jeśli w ogóle) środowiska polityczne chciałyby zmienić ustawę zasadniczą w tej kwestii.

Platforma Obywatelska stworzyła projekt nowelizacji obowiązującej w Polsce konstytucji, co oznacza, że krytycznie ocenia niektóre z przyjętych w niej rozwiązań. Został on zamieszczony w dokumencie Państwo dla obywatela. Plan Rzadzenia 2005-2009. Podstawowym postulatem tego ugrupowania jest dążenie do wzmocnienia pozycji Rady Ministrów w systemie konstytucyjnych organów państwa. Jak słusznie zauważają Bogusław Banaszak i Mirosław Granat „takie umocnienie rządu było pomyślane jako element podąża-

28 P. Winczorek, Konstytucja to nie ksiażka kucharska, [http://www.trybuna.com.pl/ n_show.php?code=2009042304; dostęp: 30.04 .2009$]$.

29 R. Markowski, Konstytucję pisze się na zawsze, [http://wyborcza.pl/1,75478,6241723, Konstytucje_pisze_sie_na_zawsze.html; dostęp: 15.05.2009]. 
nia w kierunku koncepcji egzekutywy z jednym ośrodkiem władzy. Pewna konsekwencja tego założenia przejawia się w tym, że projekt wprowadza zmiany nie tylko dotyczące rządu lub premiera, ale także instytucji podlegających głowie państwa" ${ }^{30}$. Projekt zakłada likwidację inicjatywy ustawodawczej prezydenta oraz usunięcie z ustawy zasadniczej przepisów odnoszących się do Rady Bezpieczeństwa Narodowego, a więc dekonstytucjonalizację tej instytucji. Ponadto, przewiduje określanie budżetu kancelarii prezydenta za kontrasygnatą premiera oraz ograniczenie prerogatyw w zakresie prezydenckich uprawnień związanych z siłami zbrojnymi i polityką zagraniczną. Projekt zmierza więc do osłabienia roli prezydenta.

O tym, że politycy Platformy Obywatelskiej krytycznie oceniają obowiązującą w Polsce regulację konstytucyjną w części dotyczącej władzy prezydenta, świadczą też wypowiedzi poszczególnych polityków tego ugrupowania. Donald Tusk twierdzi, że „trzeba rozpocząć debatę konstytucyjną i przedyskutować, kto ma mieć więcej władzy - prezydent czy premier”31. Podobną opinię wyraził Bronisław Komorowski, twierdząc, iż „nadszedł moment refleksji nad rozwiązaniami ustrojowymi zapisanymi w konstytucji. Raczej nie należy czekać na trudniejsze momenty w relacjach pomiędzy najwyższymi organami władzy, a próbować to przesądzić na przyszłość”32. Zdaniem Zbigniewa Chlebowskiego propozycja Tuska odnośnie debaty „to bardzo racjonalne podejście do tego, jak ma funkcjonować rząd, czy może być skuteczny i czy może realizować swoje fundamentalne projekty"33. W wywiadzie z Moniką Olejnik przeprowadzonym w maju 2009 roku, podkreśla on, że Platforma nie zdecydowała, czy chciałaby modelu prezydenckiego czy kanclerskiego, jednak konieczne jest według niej podjęcie dyskusji na ten temat. Zapytany o to, jak powinien wyglądać sposób elekcji głowy państwa, odpowiedział: „Ja myślę, że prezydent powinien być wybierany w wyborach bezpośrednich przez Polaków, ma wtedy zupełnie inny mandat, dlatego ja jestem przeciwny, mówiąc $w$ cudzysłowie, ograbianiu prezydenta $z$ jego kompetencji. Uważam, że trzeba doprecyzować pewne zapisy, trzeba [...] ograniczyć weto [...] bo w sytuacji kiedy rząd i prezydent są z dwóch ośrodków politycznych to skuteczność realizacji wielu reform stoi pod znakiem zapytania" ${ }^{34}$. Również w opinii Radosława Sikorskiego problem pozycji insty-

\footnotetext{
B. Banaszak, M. Granat, dz. cyt., s. 302.

Tusk chce zmian konstytucyjnych uprawnień prezydenta, dz. cyt.

Tamże.

Tamże.

M. Olejnik, Z. Chlebowski, Kompetencje prezydenta nie powinny być wykorzystywane w sporach, [http://wiadomosci.wp.pl/kat,1342,page,4,title,Kompetencje-prezydenta-nie-powinnybyć-wykorzystywane-w-sporach,wid,9923343,wiadomosc.html; dostęp: 8.05.2009].
} 
tucji prezydenta w systemie politycznym III RP powinien być przedyskutowany. Mówi on: „prezydent w polskim systemie ustrojowym ma «mocny mandat społeczny», ale «ubogie uprawnienia» [...]. Bardziej jednoznacznym rozwiązaniem byłoby wprowadzenie systemu prezydenckiego, bądź wybór prezydenta przez parlament" 35 .

Ponadto, politycy Platformy stworzyli projekt ustawy kompetencyjnej, która ma rozgraniczyć uprawnienia prezydenta i premiera, a premier Donald Tusk złożył do Trybunału Konstytucyjnego wniosek o rozstrzygnięcie sporu kompetencyjnego pomiędzy prezydentem a premierem. Zapytano w nim, „Czy o uczestniczeniu prezydenta w posiedzeniu Rady Europejskiej decyduje on samodzielnie, czy też, uwzględniając konstytucyjna pozycję i kompetencje poszczególnych organów państwa - ostateczna decyzja w tym zakresie należy do Prezesa Rady Ministrów"36. Rozstrzygnięcie, mówiące, iż prezydent może brać udział w posiedzeniach Rady Europejskiej, o ile uzna to za stosowne, ale to premier reprezentuje na nich Polskę ${ }^{37}$ co prawda daje odpowiedź na postawione pytanie jednak nie rozwiązuje do końca problemu rywalizacji obu podmiotów egzekutywy.

Prawo i Sprawiedliwość stworzyło całościowy projekt zmiany konstytucji, który opublikowano w lutym 2005 roku. W ramach tego dokumentu widoczna jest chęć wzmocnienia pozycji prezydenta w polskim systemie politycznym.

Partia ta proponuje zmiany w trybie zgłaszania kandydatur na urząd szefa państwa. Co ważne, „projekt PiS-u nie zalicza prezydenta do organów władzy wykonawczej. Stwarza to możliwość szerszego ujęcia funkcji prezydenta w sferze arbitrażu między innymi organami («władzami») państwowymi, jakkolwiek sam wskazany tu projekt nie rozwija szerzej koncepcji prezydentury w tym kierunku"38. Należy również podkreślić, iż PiS przyznaje głowie państwa zadanie określania „strategicznych kierunków polityki państwa", przewidując powołanie nowej instytucji o randze konstytucyjnej Rady Strategii Państwowej - organu doradczego szefa państwa.

Zgodnie $\mathrm{z}$ projektem PiS-u, prezydent miałby prawo desygnowania premiera, a na jego wniosek - ministrów. Rząd musiałby następnie uzyskać wotum zaufania sejmu. Gdyby to się nie udało, projektodawcy przewidzieli

35 Tusk chce zmian konstytucyjnych uprawnień prezydenta, dz. cyt.

36 Spór kompetencyjny prezydenta $i$ premiera $w$ Trybunale Konstytucyjnym, [http:// prawo.gazetaprawna.pl/artykuly/90863,spor_kompetencyjny_prezydenta_i_premiera_w_try bunale_konstytucyjnym.html; dostęp: 28.04.2009].

37 Zob. Prezydent może jechać, ale premier rządzi, [http://www.dziennik.pl/ polity$\mathrm{ka} /$ article383477/Prezydent_moze_jechac_ale_premier_rzadzi.html; dostęp: 25.05.2009]

$38 \quad$ M. Grzybowski, dz. cyt., s. 129. 
procedury rezerwowe. W pierwszej kolejności, wyboru premiera i rządu dokonywałaby większość sejmowa. $\mathrm{W}$ razie fiaska - prezydent miałby prawo powołania na okres do sześciu miesięcy rządu zaufania, który nie musiałby uzyskać poparcia ze strony większości parlamentarnej.

Omawiany projekt rozwiązuje kwestię przesłanek skrócenia kadencji Sejmu inaczej od obowiązującej konstytucji. Przewiduje także kompetencję głowy państwa do wydawania, na wniosek Rady Ministrów, rozporządzeń z mocą ustawy, które następnie miałyby zostać zatwierdzone przez sejm (projekt zawiera katalog kwestii wyłączonych) ${ }^{39}$. Jak słusznie zauważa M. Grzybowski „zasadnicza koncepcja [tych rozporządzeń] nie jest jasna. W szczególności trudno orzec, czy rozporządzenia Prezydenta miałyby charakter uzupełniający (w okresach niedziałania Sejmu) czy też alternatywny do ustaw (np. w przypadku braku poparcia większości dla przedłożeń rządowych)" ${ }^{\prime 40}$.

Odpowiedzią Prawa i Sprawiedliwości na propozycję Donalda Tuska odnośnie do przeprowadzenia debaty konstytucyjnej było stwierdzenie Mariusza Kamińskiego o tym, iż PiS nie jest tym zainteresowany, gdyż intencją tej partii są rzeczywiste zmiany konstytucji i to nie tylko, w ,jakimś jej małym wycinku"41.

Zdaniem polityków lewicy, warto podjąć dyskusję nad ewentualnymi zmianami w konstytucji. Jednak, zdaniem Ryszarda Kalisza „potrzeba nowelizacji ustawy zasadniczej nie może wynikać z «konfliktu charakterów» prezydenta i premiera"42. Jego zdaniem zmiany mogłyby odnosić się do uprawnień prezydenta w sytuacji, gdy rząd nie ma większości w sejmie, a sejm nie „jest w stanie” się rozwiązać. Wojciech Olejniczak z kolei, zauważa, że doświadczenie półtorarocznych sporów między Lechem Kaczyńskim a Donaldem Tuskiem wskazuje na potrzebę zmiany, zastrzega jednak, iż nie chce przesądzać, w którą stronę powinny one pójśćs ${ }^{43}$.

Polskie Stronnictwo Ludowe spogląda na ewentualne zmiany konstytucyjnych rozwiązań dotyczących urzędu prezydenta z dużą rezerwą. „Szef klubu PSL Stanisław Żelichowski uważa, że konstytucja w obecnym kształcie precyzuje uprawnienia zarówno prezydenta, jak i szefa rządu, a jednocześnie celowo niejako «zmusza» ich do współpracy dla dobra kraju [...] ewentualna

39 Konstytucja Rzeczypospolitej Polskiej. Projekt Prawa $i$ Sprawiedliwości, [www.pis. org.pl/download.php?g=mmedia\&f=projekt_konstytucji.pdf; dostęp: 28.04.2009].

${ }^{40}$ Tamże, s. 130.

${ }^{41} \quad$ Tusk chce zmian konstytucyjnych uprawnień prezydenta, dz. cyt.

42 Tamże.

43 Zob. Prezesi Trybunału Konstytucyjnego: zmieńmy konstytucje, [http://wyborcza.pl/ 1,75478,6237768,Prezesi_Trybunalu_Konstytucyjnego_Zmienmy_konstytucje.html; dostęp: 8.05.2009]. 
debata nad zmianą konstytucji przeniesie «iskrzenie» między obozem prezydenckim a rządowym na cały parlament. Dlatego - podkreślił polityk PSL-u - ludowcy liczą, że w relacjach prezydent-premier, przy dzisiejszym kształcie ustawy zasadniczej, rozsądek zwycięży nad emocjami”"44.

Własny, całościowy projekt konstytucji opracowała Samoobrona. Zawiera on wiele odrębności w stosunku do obecnie obowiązującej ustawy zasadniczej, także odnoszących się do instytucji prezydenta. Ugrupowanie to przewiduje przyznanie głowie państwa znacznie silniejszej pozycji, poprzez nadanie jej statusu „najwyższej władzy wykonawczej w państwie”. W świetle omawianego projektu prezydent sprawowałby „ogólne kierownictwo” nad Radą Ministrów, natomiast postanowienia powzięte podczas zwołanej przez niego Rady Gabinetowej uzyskałyby walor prawny uchwał rządowych.

Do prezydenta należałoby również prowadzenie polityki zarówno zagranicznej, jak i wewnętrznej oraz określanie polityki obronnej. Zadaniem Rady Ministrów byłaby zaś realizacja polityki bezpieczeństwa wewnętrznego państwa, zapewnienie porządku publicznego oraz realizacja (określonej przez głowę państwa) polityki zagranicznej i obronnej.

Ponadto, Samoobrona przyznała prezydentowi prawo mianowania premiera i członków Rady Ministrów bez konieczności uzyskania wotum zaufania Sejmu. Decyzję o tym, czy zwrócić się o nie do parlamentu czy też nie, pozostawiono swobodnemu uznaniu prezydenta.

Wzmocnieniu uległyby też uprawnienia prezydenckie w dziedzinie obronności kraju. Głowa państwa - w świetle omawianego projektu - byłaby Dowódcą Naczelnym Sił Zbrojnych oraz osobą decydującą o wojnie i pokoju.

Zgodnie z propozycją Samoobrony prezydent zyskałby także uprawnienie do mianowania prezesa Narodowego Banku Polskiego wraz z możliwością jego odwołania. Nie posiadałby już natomiast prawa rozwiązania Sej$\mathrm{mu}$ (czy też skracania jego kadencji) ${ }^{45}$.

Kolejnym ugrupowaniem, które przygotowało i zdecydowało się na opublikowanie całościowego projektu nowej konstytucji była Liga Polskich Rodzin. W kwestii związanej z prezydenturą wydłuża on kadencję głowy państwa do sześciu lat oraz przewiduje instytucję wiceprezydenta wybieranego jednocześnie z prezydentem i będącego przy tym przewodniczącym senatu.

Inną zmianą w stosunku do przepisów obecnie obowiązującej konstytucji jest - analogicznie jak w projekcie Prawa i Sprawiedliwości - przyzna-

$44 \quad$ Tamże.

45 Zob. Projekt Konstytucji Rzeczpospolitej Polskiej, [http://www.samoobrona.org.pl/pages/01. Program/index.php?document=/473.konstytucja.html; dostęp: 28.04.2009]. 
nie prezydentowi prawa do powołania rządu na okres do sześciu miesięcy, z możliwością przedłużenia o kolejne sześć ${ }^{46}$.

O konstytucyjnej regulacji dotyczącej głowy państwa piszą również publicyści. W Co z tą Polską ${ }^{47}$ Tomasza Lisa przeczytać możemy: „Zmiany są niezbędne. Powinny się zacząć od zapisów dotyczących władzy wykonawczej, prezydenta w szczególności. Nasza konstytucja wygląda tak, jakbyśmy zerkali to na Amerykę, to na Wielką Brytanię i Niemcy i w efekcie usiedli okrakiem. Mamy system ni to prezydencki, ni to kanclerski [...]. W którymś momencie trzeba będzie podjąć decyzję. Albo chcemy mieć prezydenta takiego jak Amerykanie, albo premiera takiego jak Brytyjczycy" ${ }^{48}$. Systemowi politycznemu Polski daleko $\mathrm{w}$ tym względzie do przejrzystości. Z jednej strony blisko nam do Ameryki - tam też wybiera się prezydenta (de facto) w wyborach powszechnych, z drugiej zaś strony do Wielkiej Brytanii, czy Niemiec - gdzie silną pozycję ma szef rządu. Ale skoro blisko i tu, i tu - to tak naprawdę nigdzie.

Rozważania na temat kompetencji prezydenta w kontekście sposobu jego wybierania podjął również publicysta „Wprost” - Bogusław Mazur. W swoim artykule pisze m.in.: „Urząd prezydenta Polski to ustrojowy dziwoląg - szkodliwy dla państwa i kosztowny dla obywateli. Następne wybory głowy państwa [...] powinny zatem zostać dokonane przez Zgromadzenie Narodowe - po pozostawieniu prezydentowi wyłącznie funkcji reprezentacyjnych - albo też pochodzącemu z powszechnych wyborów prezydentowi powinny zostać zagwarantowane $\mathrm{w}$ konstytucji znacznie szersze prerogatywy" 49 .

Autor słusznie podkreśla fakt, że obywatele przyzwyczajeni do bezpośrednich wyborów prezydenta ekscytują się wydarzeniami kampanii wyborczej (na którą kandydaci mogą przecież wydać po $12 \mathrm{mln}$ złotych, a jak pokazują sprawozdania finansowe $\mathrm{z}$ ostatniej kampanii wydali nawet jeszcze więcej - L. Kaczyński 13,5 mln, D. Tusk - 14,3 $\mathrm{mln}^{50}$ ), a gdy wrzucają swoją kartę wyborczą do urny czują, że wpływają na życie publiczne. W rzeczywistości jednak „Wybierają kogoś, kto będzie miał zbyt mało uprawnień, aby rzeczywiście rządzić, i zbyt dużo, aby nie ulegać pokusie rzucania kłód pod

\footnotetext{
Zob. Projekt Konstytucji IV RP autorstwa LPR, [http://www.lpr.pl/ ?sr=!czytaj\&id=2564 $\& \mathrm{dz}=$ download\& $=0$ \&pocz=0\&gr=; dostęp: 28.04.2009].

T. Lis, Co z tą Polską?, Warszawa 2003.

Tamże, s. 138.

B. Mazur, dz. cyt., s. 20.

Komunikat Państwowej Komisji Wyborczej z dnia 30 stycznia 2006 r. w sprawie sprawozdań wyborczych komitetów wyborczych uczestniczących w wyborach Prezydenta Rzeczypospolitej Polskiej, „Monitor Polski” 2006, nr 8, poz. 110.
} 
nogi rządowi" ${ }^{51}$. Znów pojawia się więc przekonanie, że należy dokonać jakiegoś wyboru.

W tym miejscu pozostaje jedynie przedstawić stanowisko społeczeństwa. W październiku 2005 roku, w sondażu CBOS-u, spytano Polaków, co należy zrobić z zakresem władzy prezydenta w Polsce. Aż 59\% odpowiedziało na tak zadane pytanie, że kompetencje głowy państwa powinny zostać zwiększone, przeciwnego zdania - a więc, że powinny ulec zmniejszeniu był zaledwie $1 \%$ badanych; $26 \%$ powiedziało, że kompetencje powinny zostać takie jak obecnie, $14 \%$ nie miało w tej kwestii swojej opinii ${ }^{52}$.

W październiku 2008 roku przeprowadzono kolejne badanie dotyczące tego, jaki model sprawowania władzy byłby najlepszy dla Polski. Pentor na zlecenie tygodnika „Wprost” zapytał: „Kto powinien mieć w Polsce więcej władzy?"; 41,1\% Polaków odpowiedziało, że premier. Zdaniem 38,6\% respondentów to prezydent powinien być „numerem 1” w państwie. 6,3\% Polaków uważa, że obaj powinni mieć tyle samo władzy, a 14\% nie ma zdania ${ }^{53}$.

\section{Podsumowanie}

Podsumowując powyższe rozważania, należy podkreślić, że zdaniem zdecydowanej większości przywoływanych w artykule naukowców, polityków, publicystów, polski ustrojodawca nie nakreślił przejrzystej koncepcji prezydentury. Dwie najczęściej przywoływane niejasności to: nieprzystawalność sposobu elekcji głowy państwa do katalogu jego kompetencji oraz nieprecyzyjne rozgraniczenie uprawnień szefa państwa i szefa rządu oraz kierowanej przez niego Rady Ministrów - zwłaszcza w dziedzinie polityki zagranicznej. Większość cytowanych konstytucjonalistów i politologów oraz przeważająca część polityków i publicystów uważa, że taka sytuacja nie jest korzystna i dla przejrzystości systemu politycznego Polski należałoby dokonać zmian w konstytucji. Część proponuje konkretne rozwiązania, część nie chce wskazywać, w którą stronę pójść. W kwestii niespójności sposobu wyboru i przyznanych głowie państwa uprawnień możliwości są następujące: można wzmocnić kompetencje prezydenta, zachowując jego powszechny wybór, albo zastąpić wybory powszechne elekcją dokonywaną przez Zgromadzenie Narodowe. W przypadku niejasnej konstrukcji egzekutywy i sporów między prezydentem a premierem, można wzmocnić pozycję szefa rządu bądź też szefa państwa, skłaniając się tym samym ku systemowi kanclerskiemu albo prezydenckiemu. Alternatywy są znane, pozostaje jed-

51 B. Mazur, dz. cyt., s. 20.

52 Zob. CBOS, Polacy o zakresie władzy Prezydenta, „Komunikat z badań” 2005, nr 177, s. 1-74.

53 Zob. Prezydentopremier dla Polski?, [http://wiadomosci.wp.pl/kat,1342,title, PrezydentopremierdlaPoski,wid,10504444,wiadomosc.html; dostęp: 28.04.2009]. 
nak pytanie, jakiego wyboru dokonać i ewentualnie: kto ma zdecydować? Bo choć większość cytowanych w niniejszym artykule osób sygnalizuje potrzebę zmian, to przeważająca część nie przesądza o ich kierunku. Również opinia publiczna nie jest zdecydowana, kto powinien mieć w Polsce większą władzę. Badania z roku 2005 zdawały się wskazywać, że społeczeństwo opowiada się za wzmocnioną pozycją głowy państwa, jednak te - przeprowadzone trzy lata później pokazały, że zwolennicy silnego premiera to grupa liczniejsza niż popierający wzmocnienie władzy prezydenckiej. Dyskusja pozostaje więc otwarta. 


\section{Abstract}

The purpose of this article is to brighten how the Polish Constitution from April $2^{\text {nd }} 1997$ regulates the institution of the President of the Republic. It is also an attempt to present how the president is perceived by Polish scientists (constitutionalists, sociologists, political scientists) and the public opinion.

According to the most of the evoked scientists, politicians and commentators polish constitution is not clear when it comes to the institution of the President. Two mainly mentioned ambiguities are: inadequacy of the President elections to the catalogue of his powers and imprecise distinction of power between the head of state and head of the government in leading the Council of Ministers - especially in the field of foreign policy.

Most of the quoted constitutionalists and political scientists and a vast majority of politicians and commentators presume that such situation is not transparent and beneficial to Polish political system and some changes should be made in the constitution. According to them, most of the problems in the Polish system could be solved simply by changing the constitution, but none of the mentioned gives precise and conrete solution to be implemented in the act.

Therefore, the main question still remains: should we create presidential system or maybe a chancellor system? The debate is still open. 